\title{
ALGUNAS CONSIDERACIONES SOBRE EL ESTUDIO DE LA LITURGIA PROCESIONAL Y PARALITURGIAS A TRAVÉS DEL ARTE EN LA ORDEN DE PREDICADORES EN CASTILLA*
}

\author{
Mercedes Pérez Vidal \\ Universidad Nacional Autónoma de México, \\ (CH-CIALC-UNAM) \\ mercedespvidal@gmail.com
}

\section{Resumen}

El estudio de la liturgia y celebraciones a ellas asociadas, así como del arte en relación a estas, han tenido escasa fortuna en el caso de la Orden de Predicadores en Castilla. Consecuencia de ello ha sido el desconocimiento y una cierta minusvaloración del papel de los dominicos en la definición y difusión de algunas prácticas devocionales, litúrgicas y teatrales. Un segundo problema ha sido la ausencia de un enfoque de género en el estudio de la liturgia y el arte de la Orden, consecuencia de la dispersión de las fuentes litúrgicas procedentes de monasterios femeninos, pero también de la falta de una correcta interpretación de otros "documentos": los edificios y los objetos artísticos y de uso litúrgico. Este artículo pretende analizar tales problemas. Por un lado, evidenciando cómo, al igual que en el caso mejor conocido de los franciscanos, los dominicos también desarrollaron ciertas prácticas devocionales, litúrgicas y paralitúrgicas, siendo incluso en algunos casos pioneros. Por otro lado, destacando el papel de las monjas en el desarrollo de tales celebraciones, así como la originalidad y diversidad de las mismas de un monasterio a otro, evidenciando también la importancia de la influencia del contexto litúrgico local en su origen y desarrollo.

\section{Palabras clave}

Orden de Predicadores, liturgia procesional, paraliturgias, Via Crucis, monjas.

* La redacción de este artículo se llevó a cabo durante mi estancia en el CIALC-UNAM, como beneficiaria de una de las ayudas del Programa de Becas Postdoctorales de la UNAM. 


\section{Abstract}

The study of liturgy and other ceremonies linked to it, as well as their relationship with the art and architecture have been scarcely explored in the particular case of the Order of Preachers in Castile. Consequence of that has been the ignorance and a certain disregard of the Dominicans' role in the definition and spreading of some devotional, liturgical and also theatrical practices. A second problem has been the absence of a gender approach in the analysis of both the liturgy and art of the Order, as a result of the scattering of liturgical written sources coming from Castilian Dominican nunneries, as well as to the lack of a correct understanding of other "documents": the buildings and the artistic and liturgical objects. The purpose of this article is to consider these problems. On one hand, showing how, as well as in the better known case of Franciscans, Dominicans also developed some devotional, liturgical and paraliturgical practices, being in some cases precursors. On the other hand, highlighting the role of nuns in the development of such ceremonies, as well as the originality and diversity of these rituals from one nunnery to another, showing also the importance of the liturgical local context's influence.

\section{Keywords}

Order of Preachers, processional liturgy, paraliturgies, Via Crucis, nuns.

\section{LA LITURGIA PROCESIONAL Y SU ÁMBITO EN LOS MONASTERIOS DE LA ORDEN} DE PREDICADORES. LA NECESIDAD DE UN ENFOQUE DE GÉNERO

Los confines entre la liturgia procesional y ciertas prácticas paralitúrgicas resultan en ocasiones poco definidos. Las procesiones asociadas a las festividades más importantes fueron enriquecidas con distintas antífonas, responsorios y oraciones, a fin de destacar su importancia, dando lugar a una complicación litúrgica que abrió el camino al drama sacro (Cátedra, 2005, p. 25).

Las descripciones de tales celebraciones en consuetas aportan interesante información sobre los distintos espacios conventuales y monásticos. Lamentablemente, sin embargo, en muchos casos estas no nos han llegado, y son entonces los libros litúrgicos, y en concreto las rúbricas de las procesiones las que más datos nos aportan respecto a la topografía eclesial y claustral. En concreto, en el caso de los dominicos, las distintas partes de la iglesia aparecen descritas con sumo detalle en los procesionarios en el caso de la celebración de Completas y en la procesión del domingo de Ramos (Gilardi, 2006, pp. 27-28). 
Un importante factor a considerar es la necesidad de un verdadero enfoque de género, que tenga en cuenta las diferencias en la funcionalidad espacial de conventos y monasterios femeninos, hasta el momento ausente en el estudio de la arquitectura dominica en Espańa. Al respecto debemos tener presente que si bien la clausura constituyó con frecuencia un condicionante, motivando la existencia de ámbitos celebrativos y procesionales distintos o específicos de los monasterios femeninos, no siempre fue observada, o se interpretó de distinta manera de un monasterio a otro, algo que se perpetuó después de Trento (Creytens, 1965).

Así pues, es importante analizar cuidadosamente en cada caso las relaciones, dependencias y diferencias de los monasterios femeninos con respecto a la Orden, y en concreto con los conventos masculinos cercanos. Tal propósito plantea un escollo fundamental: el desconocimiento de los libros litúrgicos, y por ende de la liturgia, propia de las monjas y particular de cada monasterio.

Los libros litúrgicos aprobados de forma oficial por la Orden fueron redactados para los frailes, y no fue hasta el siglo XIX cuando se publicaron los primeros ceremoniales compuestos ex profeso para las religiosas, como fue el de Ambrosio María Potton. Así pues, serían los ejemplares manuscritos de cada monasterio los que nos hablarían de estas peculiaridades, diferencias, o similitudes. Sin embargo, en España estos apenas han sido estudiados, en buena parte debido a las dificultades en el acceso a los mismos pero también por la pérdida y dispersión de estos. Esto último no solo fue consecuencia de los avatares decimonónicos y del $\mathrm{xx}$, o de la precariedad económica que obligó a su venta, sino que, especialmente aquellos sin notación musical, fueron reemplazados y desechados a raíz del movimiento reformador en el seno de la Orden, entre finales del xv y mediados del xvi. En concreto, a partir de la reforma litúrgica acometida a partir del capítulo general de Salamanca de I551, que prosiguió con la aprobación del nuevo breviario y misal por Pío $\mathrm{V}$, en 1568 y 1570 respectivamente. ${ }^{\mathrm{I}}$

Allí donde síse han conservado, en cambio, nos hablan de esta heterogeneidad de prácticas en el desarrollo de la liturgia procesional. Entre todos ellos, los más valiosos son los procesionarios, pues con frecuencia aportan indicaciones topográficas precisas de los espacios monásticos por los que se desarrollaban las proce-

${ }^{1}$ Otro factor, que estuvo estrechamente relacionado con este último, fue la invención de la imprenta, que ocasionó la devaluación de todos los códices manuscritos cuya letra gótica y abreviaturas los hizo cada vez más ilegibles, y que fueron arrinconados. Sobre estos asuntos Pérez Vidal, M., "La liturgia procesional de Completas en el ámbito de los monasterios femeninos de la Orden de Predicadores en Castilla", Hispania Sacra (en prensa). 
siones. Además, curiosamente, aunque se documenta su existencia en conventos masculinos, la mayoría de los conservados proceden de comunidades femeninas (Hamburger, 2000, pp. 78-79). Con frecuencia se describe en ellos la entrada de sacerdotes y religiosos en la clausura, a fin de oficiar determinadas ceremonias, como sucede por ejemplo en la detallada descripción de la procesión del día de Ramos en el ceremonial y procesionario de Oetenbach del siglo XIV (Munich, Bsb, cgm I68, ff 54v-55v, cit. en Jäggi, 2000, p. I03). Lamentablemente, la riqueza en libros litúrgicos de algunos monasterios de dominicas europeas, como San Luis de Poissy, Santa Catalina de Núremberg, Unterlinden, o los boloñeses de Santa María Magdalena di Val di Pietra y Santa Inés contrasta dramáticamente con la penuria de los monasterios españoles. Entre los escasos libros conservados cabe citar un ritual de profesión (ca. I525-1550) de las dominicas segovianas ${ }^{2}$ y el corpus de Santo Domingo el Real de Toledo, en el que se incluye un breviaro compuesto entre los siglos XIV y Xv (Archivo de Santo Domingo el Real de Toledo, Ms 06/508), así como cuatro antifonarios realizados en la segunda mitad del siglo Xv (Galán Vera, Martínez Gil, Peñas Serrano, 2005, pp. 279-293, no I6-19). El resto de los libros toledanos son posteriores y, en el caso de aquellos que no presentan notación musical, se trata de ediciones impresas.

Aunque, como queda dicho, no contamos con libros litúrgicos oficiales para las religiosas, ya en las constituciones de frailes y monjas, aprobadas por Humberto de Romans en 1256 y 1259 respectivamente, se evidencia la falta de uniformidad en la celebración litúrgica y en el uso del espacio. Sobre el oficio se indicaba a las religiosas que in ecclesia tractim et distincte taliter dicantur (Constitutiones et Acta Ordinis, 2002, p. IIo), mientras que los frailes debía recitar las horas breviter et succinte (Constitutiones et Acta Ordinis, 2002, p. 35). No solo esto, sino que encontramos diferencias bien precisas en cuanto a la funcionalidad espacial, como, por ejemplo, en el rezo del oficio de la Virgen, para el que en el caso de los monasterios femeninos se indica que prius horas canonicas dicantur in ecclesia (Constitutiones et Acta Ordinis, 2002, IOI), esto es, en el coro. Por el contrario, los frailes debían recitar dicho oficio extra chorum praeter Completorium. Consuevit autem dici inter duo signa Horarum canonicaroum (Ordinarium, I92I [I256], II5), normalmente en el dormitorio y frente a una imagen mariana (Bonniwell, I945, p. 134)

La cosa se complica aún más si tenemos en cuenta que no siempre se observó esta disposición y que, como se indicó arriba, debemos revisar en cada caso par-

${ }^{2}$ Archivo de Santo Domingo el Real de Segovia, Forma y manera de cómo las monjas del orden de Sancto Domingo de los Predicadores han de hacer profesión a sus priora (ritual de profesión). 
ticular la relación de las religiosas con los frailes, la mayor o menor dependencia respecto a estos, la imitación o los usos propios, y la importante influencia de la liturgia local, como se verá a continuación.

\section{LEGENDAE MARIANAE. OBJETOS, TEXTOS Y CONTEXTOS}

Como ejemplo de esta falta de unidad y observancia de la normativa, tenemos la celebración del citado Oficio de la Virgen. Contraviniendo lo dispuesto en las Constituciones de I259, en algunos casos las monjas siguieron la costumbre de los varones de celebrar dicho oficio en el dormitorio. Así sucedió en Santo Domingo el Real de Madrid, ante la llamada Madona de Madrid (Vidal, I946, pp. 6I-64) o en Quejana ante el relicario de la Virgen del Cabello, que diariamente era portado en procesión al coro de las religiosas, tras el rezo de prima, entonando procesionalmente el Ave Maris Stella. Aquí permanecía todo el día hasta después de maitines, cuando era devuelto de igual forma al pequeño oratorio del dormitorio, cantando el himno O Gloriosa Domina (Archivo San Juan Bautista de Quejana, La Lastra, I756, cit. en Martínez Vázquez, 1975, p. I2).3

En algunos casos parecen haber existido incluso espacios ex profeso para la celebración de los maitines de Nuestra Señora. En este sentido, si bien se trata de un ejemplo tardío y en América, resulta muy interesante el caso de Santo Domingo de Oaxaca. El coro alto de los frailes estaba precedido por una dependencia, suerte de anteocoro, comunicada también con el dormitorio, conocia como Sala de Dómina. Según describe Burgoa, esto se debía a que en ella se rezaba diariamente el oficio de Nuestra Seńora antes de entrar a maitines en el coro:

"donde se reza el oficio de Nuestra Señora antes de entrar a Maitines, esta estación es una maravilla, toda de artesonería dorada, en medio de la clave una imagen de la Purísima Concepción de media talla y de dos varas de cuerpo, de tan rara hermosura, que basta para inflamar con la devoción de este soberano misterio, es cierto que parece milagro, y le siguen en cuadro más bajo los cuatro evangelistas con sus jeroglíficos de animales como de la mesma mano [...] es lugar este de grandísima devoción que se cierra para el dormitorio con reja y llave, y para la puerta del coro que está inmediato, otra llave, de día que se llegue aquí huele a santidad y devoción, y la infunde con asombro a todos los que lo ven;

3 Se trata una vez más de una referencia tardía, pues la encontramos en una descripción del padre La Lastra en 1756, quien describe sendas procesiones. La Lastra, P. de., 1756: Fundación del convento de Religiosas Dominicas de San Juan Bautista del Lugar de Quejana, en esta Tierra de Ayala para darse a la historia. Archivo San Juan Bautista de Quejana, Ms. Aprt.2, Leg. I4, núm. 20. 
tiene altar donde se celebra, sagrario,lámpara y ternos frontales y casulla de importancia" (Burgoa, 1989 [1674], I, pp. 203-21I)

Si bien no se ha conservado, conocemos gracias a la descripción realizada por el padre Gonzalo de Arriaga en I650, que existió una sala del mismo nombre y función en el convento de San Pablo de Burgos, situada en la panda meridional previa al dormitorio, y presidida por una imagen de la Virgen del Rosario, aunque sin comunicación con el coro en este caso (Arriaga, I972 [I650], II, fol. I29 $\mathrm{v}^{\mathrm{o}}$, cit. en Casillas, 2003, p. 275). Asimismo, teniendo en cuenta estos ejemplos, no debemos descartar la existencia de dependencias semejantes en época medieval en otros monasterios y conventos españoles. Quizás espacios hoy desaparecidos, o bien reutilizados con otra funcionalidad.

Tanto la mencionada Madona de Madrid como el relicario de la Virgen del Cabello no solo fueron el foco de las devociones y de las celebraciones litúrgicas relacionadas con la Virgen en sus respectivos monasterios, sino que tuvieron también un papel fundamental en la construcción de la memoria y la identidad de estas comunidades monásticas. La diferencia que presentaron respecto a otros objetos o imágenes similares fue su carácter privado o semiprivado. La imagen de las domincias madrileñas, de hecho, no tuvo fama más allá de sus muros, entre los que permaneció oculta y desconocida hasta fechas bien recientes. Por su parte el relicario tuvo un uso semiprivado en tanto que, además de presidir el dormitorio o coro de las monjas, es posible que también se colocase, en determinadas ocasiones, en el altar de la capilla homónima fundada por el Canciller de Ayala (Tormo, 1916, p. 156), ${ }^{4}$ que en todo caso tendría un uso restringido al estar destinada a las monjas y a sus patronos.

Muy distinto fue el caso de otras imágenes marianas supuestamente milagrosas, como la Virgen de los Huertos de Medina del Campo, que en la festividad de la Natividad de la Virgen, el 8 de septiembre, abandonaba la clausura y era sacada

4 Frente a otras hipótesis sugeridas, en mi opinión la más acertada fue la planteada por Tormo, que consideró que el retablo de la capilla, actualmente en el Art Institute of Chicago, debió estar presidido por un ciborium, de forma permanente o en alternancia con el mencionado relicario, algo que viene apoyado por el significado eucarístico de la escena de la Adoración de los Magos, los cuales se dirigen precisamente hacia el vano central del retablo. De ser cierto esto se trataría de un ejemplo de la conservación del Santísimo Sacramento fuera del altar de la iglesia, contraviniendo las disposiciones de Humberto de Romans al respecto. Si bien en el caso de las clarisas tal cuestión ha sido bien estudiada, una vez más las dominicas no han tenido igual fortuna historiográfica. No me detendré aquí más sobre estas cuestiones que he abordado en un artículo de próxima publicación. Pérez Vidal, M., 20I6: "The Corpus Christi Devotion: Gender, Liturgy and Authority among Dominican Nuns in Castile in the Middle Ages", Historical Reflections 2016 (en prensa). 
en procesión a la iglesia (Medrano, I725-I734, Tercera Parte, Tomo I, ff. 63-84). Asimismo, otros dos iconos marianos, no espańoles, eran venerados en la iglesia por los laicos: la Madonna de San Sisto en Roma, y el icono mariano de Unterlinden, donde las monjas parecen haber compartido con los fieles la adoración del mismo, adoptando una solución arquitectónica que permitiese conjugar esto con el debido ocultamiento de las religiosas (Jäggi, 200I, pp. 95-97).5 Las legendae de ambos iconos fueron copiadas en respectivos libros de carácter litúrgico o paralitúrgico, destinadas a ser leídas e interpoladas en la celebración del oficio divino. En el caso de San Sixto, lo fue en un leccionario a inicios del siglo xIv, y se insertó como lectura en los maitines del oficio de la Beatae Mariae Virginis in sabbato, celebrado entre el 22 y 28 de abril. Se conmemora de esta forma la traslación de la imagen desde Santa María in Tempulo en I22I, evidenciando también reminiscencias de los usos litúrgicos de este monasterio benedictino (Berthier, I889, App. doc. I; Koudelka, I96I)

La interpolación legendae en los maitines del Oficio de la Virgen del Sábado, ligada a la memoria monástica, y también con un claro vínculo con la liturgia local no fue algo exclusivo de San Sixto. La misma función tuvieron las Historie de beata virgine in sabbatis, insertas en el breviarium portatile procedente de Santo Domingo el Real de Toledo (Fueyo Suárez, 2009, p. 382). Se trata de nueve lecturas, en lugar de las tres de este oficio, y están tomadas del tratado $D e$ Virginitate perpetua Sancte Marie de San Ildefonso. Esto permite relacionarlas con la celebración de la Expectatio Partus, el i8 de diciembre, cuya institución estuvo estrechamente relacionada con la citada obra e incluso llegó a atribuirse a San Ildefonso la composición de la misa Erigamus quaeso para dicha festividad. El X Concilio de Toledo del 656 fue el que decidió el traslado de la Anunciación al I8 de diciembre, para evitar su coincidencia con la Pascua. Además, pese a la introducción de liturgia romana a finales del XI, la festividad visigótica continuó en España, como demuestran los sínodos, y fue a partir de 1330 cuando recibió el nombre de la Expectación (Rucquoi, I998, pp. III, II8, I22).

5 Según las fuentes escritas, este se encontraba en un altar situado sobre una bóveda (gewelb, borkirche o testitudo). Carola Jäggi señaló que la traducción alemana de las Vitae sororum parecería indicar que se trataba del lettner. No obstante, si bien la existencia de altares en una plataforma del lettner fue algo habitual, también señala esta autora que, de ser así, resultaría muy difícil explicar cómo se regularía el acceso de los peregrinos al mismo respetando la clausura de las monjas. Así pues, podría tratarse más bien de otro tipo de estructura, quizás una galería a los pies, de acuerdo con el significado del término borkirche, antigua palabra alemana equivalente al término Emporenkirche, esto es, iglesia con galería. Agradezco a Reinhard Köpf que me haya proporcionado esta información y sugerido tal posibilidad. 
3. ARTE, LITURGIA Y TEATRO EN TORNO A LA PASCUA Y LA NAVIDAD. RECONSIDERANDO EL PAPEL DE LOS DOMINICOS

La interpolación de este tipo de lecturas, o legendae, a veces en latín, pero más frecuentemente en lengua vernácula, normalmente en el oficio de maitines, se dio también, lógicamente, en otras festividades o momentos del calendario litúrgico. Como es sabido, el tropo Quem quaeritis in sepulcro, inserto en el introito de la misa Pascual, a imitación del cual se insertó el Quem quaeritis in praesepe en la misa de Navidad, dieron origen no solo al desarrollo del drama litúrgico, sino también del teatro vernáculo. Los dramas litúrgicos surgidos a partir de dichos tropos salieron de la misa y se insertaron al final de los maitines de sendas festividades. Sin embargo, fuera de Cataluña, no se han conservado en España dramas litúrgicos asociados a la Navidad, con excepción del Canto de la Sibila, ni tampoco parece haber existido teatro vernáculo entre el aislado Auto de los Reyes Magos de Toledo del xir y el desarrollo del teatro a finales del xv. ${ }^{6}$ No obstante, sí existieron otro tipo de ceremonias que, aunque no puedan ser consideradas teatro sensu stricto, implicaron cierta dramatización, como por ejemplo el canto alternativo de antífonas en los laudes del Navidad que tenía lugar desde el xiv en la catedral de Toledo, al que se le añadieron villancicos y elementos vernáculos en la siguiente centuria (Surtz, I97I, p. I7).

Asimismo, también en el ámbito monástico encontramos ejemplos de interpolaciones vernáculas en la liturgia con cierto grado de dramatización, como los poemas en romance con música polifónica centrados en el ciclo navideño del llamado Códice de Astudillo, compuesto a mediados del xv. La posterior adición

${ }^{6}$ La falta de testimonios teatrales en Castilla en ese lapso llevó a algunos estudiosos, como Donovan y Surtz, a negar su existencia, la cual el primero justificó por cuestiones litúrgicas y el segundo por cuestiones de índole histórico-política (Donovan, 1958, pp. 5I-68 y Surtz, 1979, pp. I622). Otros se han mostrado, en cambio, más renuentes a aceptar la aparición de un teatro ex nibilo a finales del xv sin ningún precedente, señalando además cómo las prohibiciones y leyes existentes al respecto-las Siete Partidas o el Concilio de Valladolid de I228-serían pruebas precisamente de su existencia. (Álvarez Pellitero, 1985, pp. 13-35). Horcasitas apuntó cómo, al igual que sucedió con el teatro Náhuatl en Nueva España, la ausencia de textos se habría debido a que se trató sobre todo de una tradición oral, transmitida de generación en generación. Asimismo, como prueba de la existencia de un bien desarrollado teatro vernáculo en Espańa durante el medievo, apunta también que el teatro desarrollado por los frailes en América aparece claramente como continuación de esa "perdida" dramaturgia medieval. En concreto señala las similitudes con los autos contenidos en el Códice de Autos Viejos (Biblioteca Nacional de España, ms. I47II; Horcasitas, 2004 [1974], 69-70). Dicho códice fue editado íntegramente por Léo Rouanet en I90 Coleción de autos, farsas y coloquios del siglo XVI, Barcelona, I9OI, 4 vols. 
a dichos poemas de un procesionario de origen franciscano evidencia la función paralitúrgica de este curioso códice (Cátedra, 2005; p. 25). Su descubrimiento se sumó a otra serie de autos o representaciones procedentes igualmente de monasterios de clarisas castellanas, ya estudiados por Surtz (Surtz, I983, pp. I4I-I52). ${ }^{7}$ Todos ellos han abundado en la consideración del papel preeminente, cuando no exclusivo, de los franciscanos en la génesis de un teatro religioso navideño no estrictamente litúrgico, que en última instancia remontaría sus orígenes al belén de Greccio (Buenaventura, I898, p. III).

Sin embargo, al igual que sucedió con el citado códice de Astudilo, debemos tener presente que, aunque no se haya considerado en muchos casos, también otras composiciones poéticas o musicales insertas en libros de horas, devocionarios u otro tipo de obras de carácter misceláneo, pudieron estar destinadas ser interpoladas en la liturgia. Así sucedió muy probablemente con el Codex $M a-$ tritensis, en cuyas guardas una monja insertó una loa de la Virgen centrada en el nacimiento de Cristo, o con el Libro de Devociones y Oficios de Constanza de Castilla, ambos procedentes de Santo Domingo el Real de Madrid (Wilkins, I998; Cátedra, 2005, pp. 136-I42). Respecto a este último, no debe extrañar la inserción en la liturgia comunitaria de oraciones contenidas en un devocionario personal, ya que la división entre devoción y oraciones privadas, constituye una clasificación artificial y realizada desde la óptica contemporánea, sin que estuviese presente en tiempos medievales (Boyton, 2007, pp. 896). ${ }^{8}$

Asimismo, junto a los textos, también a través de una atenta lectura y recontextualización tanto de la arquitectura como de imágenes y objetos, podemos formular hipótesis acerca del desarrollo de tales celebraciones. La duplicación del Anuncio a los Pastores y Adoración de los Magos en el frontal y retablo de San Juan Bautista de Quejana (Art Institute, Inv: 1928.8I7), que se ha justificado por el carácter local de la obra (Melero Moneo, 2000-200I, p. 46), debió ser, a mi juicio, intencional. Como se ha seńalado en otros casos (Schmidt, 2009, p. 220),

7 Representaçion del Nasçimiento de Nuestro Señor escrita por Gómez Manrique para su hermana, monja clarisa en el monasterio de Calabazanos; el anónimo Auto de la huida a Egipto, conservado en un manuscrito procedente del convento de clarisas de Santa María de las Bretonera; las Contemplaçiones que Juan Álvarez Gato escribió probablemente para una comunidad de clarisas Madrileñas, o el anónimo Auto de la Asunción

${ }^{8}$ El manuscrito 2322 de la biblioteca Cranston, realizado en el siglo xv y procedente del monasterio de las clarisas de Aldgate, parece haber tenido este mismo carácter ambivalente o híbrido. Clasificado tradicionalmente como Libro de Horas — al igual que el ejemplar de Constanza — resulta en realidad difícil de catalogar pues participa de ciertos aspectos de los libros de horas, salterios, breviarios y procesionales (Yardley, 2009, p. I8). 
muchos de estos frontales eran mostrados solo en determinadas festividades, y este podría haber sido también el caso de Quejana, en Navidad, asociándose quizás a una representación de la que no hemos conservado el texto porque posiblemente nunca lo hubo, sino que se transmitió de forma mnemotécnica. ${ }^{9}$

De igual forma, en Santo Domingo el Real de Toledo, una cuna relacionada con sor Juana de Herrera y un Romance del Nascimiento de nuestro Salvador, compuesto en 1485 por fray Ambrosio de Montesino para esta misma religiosa, nos hablan claramente de la celebración de la Navidad en el monasterio toledano. A esto se suma la existencia de una dependencia en la que encontramos una inscripción en el friso que recorre los cuatros muros con texto perteneciente a los maitines de Navidad (Ordinarium I92I [I256], p. II). Tanto la presencia del citado friso, como las dimensiones de este espacio y su extrańa ubicación entre el coro monástico y el claustro procesional del Moral, me llevan a considerar que, en contra de lo que se ha reiterado en la bibliografía sobre el monasterio, este no fue una sacristía. Muy al contrario, se trató muy probablemente del escenario de la celebración de la Navidad, y quizás también de otras festividades (Pérez Vidal, 2013, pp. 334-34I).

Lo mismo sucedió en el caso de las celebraciones asociadas a la conmemoración de la Pasión de Cristo, donde también se ha insistido en ocasiones en el papel pionero y casi exclusivo de los franciscanos en el desarrollo de ciertas prácticas vinculadas a la misma, como el Via Crucis, del que se hablará más adelante. ${ }^{\text {IO }}$ Sin embargo, también aquí, como se verá, los dominicos tuvieron un papel destacado.

Tras la mencionada celebración del domingo de Ramos, tenía lugar el Triduo Sacro, cuyas procesiones están también perfectamente definidas en el procesionario dominico. El Miércoles Santo se había retirado la cortina que desde el primer domingo de Cuaresma separaba el presbiterio del coro de los frailes, según las rúbricas humbertinas (Romans, I921, p. 157). Lamentablemente, la mayor parte del ajuar litúrgico medieval de las fundaciones dominicas en España no ha llegado hasta nosotros. Los ejemplos conservados son tardíos, como las siete sargas destinadas a paramentar la iglesia del monasterio de Sancti Spiritus de Toro du-

9 Como ha señalado Horcasitas para el caso del teatro Náhualt. Véase nota 6.

Io También en el caso del teatro Náhualt, los franciscanos son considerados los creadores e introductores del mismo. Sin embargo, esto solo es válido para determinadas zonas y se explica por el reparto territorial efectuado por las órdenes mendicantes en Nueva España. En otros lugares, como la región zapoteca de Oaxaca, controlada por los dominicos, fueron estos quienes tuvieron un destacado papel en el desarrollo de un drama religioso (Horcasitas, 2004, pp. 52I-525). 
rante el ciclo litúrgico de la Pasión (Navarro Talegón, 1980, p. 245). Asimismo, es probable que la iglesia de las dominicas vallisoletanas de Santa Catalina hubiese contado con colgaduras semejantes, según se recoge en el libro de profesiones de este monasterio ( Aniz Iriarte, 1988, p. IIO).

El Jueves Santo (Feria $V$ in coena domini), tenían lugar dos ceremonias: ad altaria abluenda y mandatum. La primera implicaba la purificación de todos los altares consagrados, entonando la antífona correspondiente al santo titular. Al respecto, contamos con un precioso documento para San Luis de Poissy (Ordo altarium abluendorum in cena domini in ecclesia beati Ludovico de Pissiaco [ff. 34v. 4IV]), contenido en el procesionario, y que nos permite conocer la topografía de su iglesia, con la ubicación precisa de sus veintiún altares (Moreau-Rendu, I968, p. 56). Finalizada esta ceremonia, frailes o monjas se trasladaban al capítulo donde tenía lugar el mandatum

Seguía el Viernes Santo o de Parasceve con la adoración de Cruz, situada sobre el altar y velada, a la que se acercaban los frailes por orden jerárquico (Fueyo Suárez, 20Io, pp. 75-76.). Tras esto tenía lugar la Depositio o Santo Entierro, en las que se emplearon una serie de imágenes — cristos yacentes, articulados o no, sepulcros, píxides y arquetas eucarísticas, etc.- llegando incluso en algunos casos a sustituirse la participación de "los actores" por uno de estos objetos (Carrero Santamaría, 2oIo, p. 83). Por último, la celebración de la Pascua se cerraba el domingo de Resurrección, en el que tenía lugar una procesión desde el coro a la iglesia cantando Xristus resurgens y otras antífonas y portando la cruz. Con el canto de la Regina celi, los frailes regresaban al coro (Fueyo Suárez, 20ı, p. 75). Obviamente, en el caso de las religiosas esta procesión tampoco se desarrollaría en la iglesia sino muy posiblemente en el claustro, donde, como se verá existieron una serie de estaciones en conmemoración de distintos momentos de la Pasión. Aunque, lamentablemente, no ha sido así en el caso castellano, en algunos monasterios, como el de Wienhausen, se conserva una figura del Cristo resucitado que era empleada en el rito de la Elevatio (Hamburger, I992, p. I22).

Los Cristos yacentes se han conservado en mayor número, aunque una vez más los únicos de cronología medieval conservados en las clausuras españolas son los de las clarisas de Zamora y Palencia (Ara Gil, 200I, pp. 623-624). Sin embargo, esto no descarta su existencia en monasterios de dominicas, ya que, de hecho, contamos con ejemplares ligeramente más tardíos, como el Cristo de Medina, de Campo, ya de inicios xVI (Hernández Redondo, J.I., 200I, pp. 256-259), ${ }^{\text {II }}$ el

II De ella se dice en el Liber Q del AGOP: “Ay otra imagen de bulto muy devota que es de la Majestad de Xpto Señor Nuestro puesto en el sepulcro está en un altar en la iglesia muy decente y 
que se conservaba en Santo Domingo el Real de Toledo y conocemos gracias a fotografías (Archivo Histórico Provincial de Toledo, Fondo Rodríguez, F-033), el de Santa Catalina de Siena en Valladolid, ya del xvir, y atribuido al taller de Gregorio Fernández (Martín González y De la Plaza Santiago, 1987, XV, p. 58). Asimismo, también por fotografías conocemos una representación pintada del Santo Entierro, que se hallaba inserta en el luneto que daba acceso a la llamada "vieja sacristía” de Santo Domingo el Real de Toledo (Archivo Histórico Provincial de Toledo, Fondo Rodríguez F-039). Por último, en este monasterio se conservaba, y conserva aún, una copia de la Santa Síndone, inédita y no documentada, similar a la de las Comendadoras de Santiago de la misma ciudad (Martínez Caviró, I990, p. 13I). Todos estos elementos nos están hablando de la importancia que debía tener la celebración del Viernes Santo. Otra representación pictórica de la Deposición de Cristo, se conservaba en la capilla situada en la zona de acceso del monasterio toresano de Sancti Spiritus de Toro(Navarro Talegón, I980, p. 245).

Tales representaciones y escenificaciones del Santo Entierro estuvieron en muchos casos influenciadas por la liturgia local, como sucedió en Medina del Campo donde al menos desde mediados del xvi existían varias cofradías penitenciales de disciplinantes. En el convento agustino de Nuestra Señora tenía lugar una dramatización de la Depositio al menos desde i622, que quedó fielmente representada en un curioso lienzo realizado en 1722 , actualmente en el monasterio femenino de Santa María Magdalena (Carrero Santamaría, 2010, pp. 79-80).

Cabe tener presente que las cofradías del Santo Entierro estuvieron estrechamente ligadas a la Orden de Predicadores tanto en España como en América, donde tuvieron un papel fundamental en los inicios de la evangelización. Además de la influencia en Nueva España de las cofradías penitenciales medievales, Estrada de Gerlero señaló también las similitudes de algunas características de la predicación de San Vicente Ferrer-tales como la necesidad de instalar altares al aire libre, para atender a la ingente multitud-como inspiradoras de algunos aspectos de la evangelización en el continente americano (Estrada de Gerlero, 1983, p. 656). Si bien la primera cofradía en Nueva España fue la dedicada a la Vera Cruz en el convento de los franciscanos en México, la que mayor trascendencia tuvo fue la del Descendimiento y Sepulcro de Cristo, que se constituyó en I582 en el convento de los Predicadores, a imitación de la existente en Roma. Además, frente a la imprecisión de los cronistas franciscanos y agustinos en la descripción de

el sepulcro muy bien labrado esta tal imagen es común tradición de todo el convento que la hizo y labró Nicodemus". Archivo General de la Orden de Predicadores, Serie XIV, Liber Q, parte segunda, f. I039; 
estas ceremonias, el dominico Agustín Dávila Padilla proporcionó en su crónica un detalladísimo relato de la primera ceremonia del Descendimiento y subsiguiente procesión penintencial que tuvo lugar en México ese mismo año (Dávila Padilla, 1995 [1596], pp. 563-568). ${ }^{12}$ Tanto la cofradía, como, especialmente, dicha ceremonia, que fue notablemente ostentosa, tuvieron gran repercusión. Esta última fue imitada en otros lugares, y conventos, no solo dominicos, y dio lugar a representaciones pictóricas. Asimismo, poco después los franciscanos instituyeron una cofradía del Santo Entierro en su propio convento de México (Vetancurt, I97I [1698], Tomo 2, pp. 42-69).

Más interesante aún resulta la representación de tales celebraciones en ciclos pictóricos. En concreto, la ceremonia y procesión de 1582 aparece representada, según Pablo Escalante, en la portería o capilla abierta del convento dominico de San Juan de Teitipac. Sigue con fidelidad la descripción de Dávila Padilla, exceptuando algunas variantes como el orden de los Arma Christi, o que las imágenes escultóricas de pasta de caña articuladas que intervenían en la escenificación del Calvario aparezcan representadas como personajes reales, de carne y hueso. Esta escena se representa en el testero, mientras que la procesión del Santo Entierro discurre por el muro derecho (Escalante Gonzalbo, 2005, pp. IO4-II4). Pero, como se ha señalado, la influencia de la celebración dominica y quizás del señalado texto cronístico trascendió la Orden, y la encontramos también en conventos franciscanos, como en el ciclo pictórico de la nave de Huejotzingo, realizado entre I57I y 1592. Sin embargo, mientras que Estrada de Gerlero consideró que se trataba de nuevo de una representación de la procesión dominica de 1582 (Estrada de Gerlero, 1983, p. 649), Susan Webster se mostró contraria a tal suposición, señalando, de acuerdo con la documentación conservada, que se trataría más bien de la procesión del Viernes Santo celebrada por parte de la cofradía de la Vera Cruz, establecida en el convento franciscano a comienzos de la década de 1590. Esta se iniciaría con la ceremonia del Descendimiento, que tendría lugar en el exterior de la iglesia, delante de la Porciúncula, mientras era leído el sermón. Posteriormente la imagen de Cristo se llevaría al interior, al altar de la iglesia, y desde allí iniciaría un recorrido procesional, que tendría las capillas posas como estaciones (Webster, 2005, pp. 33-40). En cualquier caso, el influyo de las cofra-

${ }^{12}$ Describe cómo para la ocasión se erigió un tablado del Calvario en la capilla mayor de Santo Domingo de México, con las figuras de Cristo, la Virgen y los ladrones en pasta de caña y con miembros articulados, que eran movidos para ilustrar los distintos pasajes del sermón. Una vez que este finalizaba, tenía lugar la procesión, que discurría por la ciudad con estaciones en distintas iglesias. 
días dominicas del Santo Entierro en el desarrollo de tales celebraciones en los conventos franciscanos parece claro.

Volviendo a Teitipac, junto a estas pinturas que harían alusión a la existencia de una cofradía del Santo Entierro, también encontramos, en el lado izquierdo del Calvario descrito, una representación de Santa Catalina y Santo Domingo de Guzmán a los pies de la Virgen del Rosario, y en el muro izquierdo una representación de San Francisco y Santo Domingo, ambos con los estigmas, y una procesión. Escalante relacionó estas pinturas con la cofradía del Santo Rosario que también tendría sede en el convento, señalando cómo las pinturas siguen una vez más la descripción de Dávila Padilla (Dávila Padilla, 1995, pp. 359-360; Escalante, 2005, p. II4).

4. CONMEMORACIÓN DE LA PASIÓN, PEREgRINACIONES INTRA CLAUSTRA. ¿UN "VIA CRUCIS" DOMINICO?

De igual forma que las capillas posas de los conventos novohispanos, las capillas claustrales sirvieron también como estaciones de la liturgia procesional. Así sucedía no solo durante las celebraciones de la Pascua, sino los viernes durante la Cuaresma, asociándose cada capilla a un episodio de la Pasión. En los conventos femeninos, y especialmente a partir de la reforma, fue frecuente la recreación en el interior de los muros claustrales de las procesiones que se desarrollaban en el entorno urbano conmemorando la Pasión, y en ocasiones recreando los santos lugares jerosolimitanos o las siete basílicas romanas. ${ }^{13}$ Además, estos peregrinajes virtuales recibieron de los pontífices las mismas indulgencias y privilegios que obtenían los peregrinos reales. ${ }^{14}$ En algunos casos, las religiosas contaron además con una pintura que serviría de "guía" en tales recorridos procesionales, como el panorama de Jerusalén preservado en la Madre de Dios de Lisboa (Pais y Cur-

13 En algunos casos, incluso existieron recreaciones de los lugares de peregrinación, como, por ejemplo, la reproducción de la Scala Santa, existente en el Orto del Gosto del convento de San Niccoló de Prato, Morini, Niccoli, Palamedi, 1997

${ }^{\text {I4 }}$ Por ejemplo, Alejandro VII concedió por medio de breve dirigido a las dominicas de Segovia los mismos privilegios que recibían los peregrinos a Roma, a quienes visitasen una capilla o altar localizado en el claustro cuatro veces al ańo, rezando por la eliminación de los herejes y la gloria de la iglesia. Archivo del monasterio de Santo Domingo, "Breve de Alejandro VII a la priora y monjas del monasterio. Dado en Roma, en Santa María la Mayor, bajo el anillo del Pescador el día is de septiembre de I66r. Año séptimo de nuestro pontificado". Sobre estos asuntos véase Kathryn. M. Rudy, 2oII. 
velo, 2009, p. 78) o el tríptico de las Horas de la Pasión de San Juan Bautista de Quejana (Franco Mata, 2007, pp. 436-439)

En Santo Domingo el Real de Toledo las dominicas hacían penitencia cada viernes durante la Cuaresma en una habitación situada en el piso superior del claustro del Moral, cantando el Miserere frente al llamado Cristo de las Aguas - o una Piedad. Cabe tener en cuenta que cada vano de esta panda del claustro estaba además decorado con los Arma Christi, que se asocian a un contexto funerario, pero también penitencial, como se ha visto en el caso de las cofradías novo hispanas, y las Cinco Llagas, también con estas connotaciones, a las que cabe sumar que fueron el emblema de las cofradías del Rosario. En efecto, en el vecino convento de San Pedro Mártir se había constituido una cofradía del Rosario y el emblema de las Cinco Llagas aparece decorando los libros corales y folios sueltos de estos que han sobrevivido de la misma (Candelaria, 2008). Todo esto apunta a un uso procesional asociado a la Pasión de Cristo de esta panda claustral, levantada entre 1507 y I508, amén de servir también, como prueban distintos elementos y he tratado en otro lugar, como escenario para las procesiones que tenían lugar tras Completas (Pérez Vidal, 2013, pp. 192-195). ${ }^{\text {Is }}$

Ejemplos de estos tipos de prácticas penitenciales exacerbadas fueron la Beata de Piedrahita, quien además probablemente influenció las devociones y prácticas de las dominicas toledanas entre 1507 y I508, y quizás determinó la construcción de este nuevo claustro (Pérez Vidal, 20I2; pp. 804-805), y el beato Suso. Este último relató cómo el mismo recorría una especie de Via Sacra con diferentes estaciones en altares localizados en el claustro, el capítulo y el coro, que simbolizaban otros tantos lugares jerosolimitanos. Esta Vía Sacra era recorrida de dos maneras y en dos momentos distintos: cada noche tras maitines, y después del canto de la Salve Regina tras Completas (Suso, I865, pp. 5I-56). Teniendo en cuenta el más que probable uso de esta panda claustral del monasterio toledano para la celebración de Completas, como se ha señalado, no debe descartarse que las dominicas toledanas recorriesen también aquí una especie de Via Sacra, cuyas estaciones estarían marcadas con las representaciones de las Cinco Llagas y los Arma Christi. De ser así, es probable que portasen los instrumentos de la Pasión, como hacían, por ejemplo, las cistercienses cordobesas (Cerrato Mateos, 2005, p. 224), o bien la cruz, de forma similar a una curiosa pintura procedente del

is Me dedico específicamente al desarrollo de la liturgia de Completas en un artículo de próxima publicación. Véase nota I. 
monasterio dominico de Saint Gertrud de Colonia (Wallraf-Richartz Museum, 342, Juta Prieur, 1983, p. III). ${ }^{16}$

Asimismo, también en Medina del Campo existieron una serie de capillas asociadas a otros tantos episodios y lugares de la Pasión de Cristo, tal y como podemos leer en una descripción hecha por fray Gaspar de Alarcón en el siglo Xvir: la agonía en Getsemaní, la subida al Calvario, otra que contenía una pintura conocida como el Santo Cristo de la Vestidura, que probablemente representaba el Expolio de Cristo. A estas capillas cabe sumar la dedicada al Crucifijo, inicialmente en la sala capitular, hasta que fue trasladado al coro (Archivo General de la Orden de Predicadores, Roma, Serie XIV, Liber Q, seconda parte, f. I040).

Por último, junto al citado ejemplo de Suso, cabe traer también a colación el de fray Álvaro de Córdoba, impulsor de una fallida reforma de corte eremítico de la Orden de Predicadores a comienzos del xv, que, si bien no tuvo continuidad sí que debió dejar su impronta en los dominicos españoles. Fray Álvaro peregrinó a Tierra Santa en I405 y, años después, en I422, movido por la devoción que profesó desde su viaje a los Santos Lugares, solicitó ser liberado de su cargo de confesor real, trasladándose a Córdoba, en cuya sierra fundó el convento de Scala Coeli al ańo siguiente. La nueva fundación pretendió recrear la topografía de los lugares jerosolimitanos, construyendo para ello varias capillas en las que representó los principales eventos de Nuestro Señor camino del monte Calvario. Lamentablemente, dichas escenas no se conservan pero fueron descritas por J. B. Feuillet en el siglo XviI (Feuillet, I678-I680, pp. 647-648). Si bien se ha objetado que no constituyó un Vía Crucis, por contar únicamente con ocho estaciones y porque, aunque meditaba sobre los momentos de la Pasión, el beato no acompañaba a Cristo en su Vía dolorosa, característica fundamental del Vía Crucis (Da Zedelgem, 2004, p. 96), no cabe duda de que constituyó un precedente directo,. y que puede relacionarse con los Sacri Monti que a partir del siglo xv, y de forma especial tras el Concilio de Trento, proliferaron en distintos lugares.

Respecto al Vía Crucis, el origen de este último, en su forma conocida actualmente de catorce estaciones, sigue resultando controvertido. Frente a quienes lo

${ }^{16}$ En ella aparecen representadas dos monjas dominicas llevando la cruz, frente a un Cristo resucitado que las recibe con las palabras komt in ynen wyngar. Además, sobre la cruz podemos leer Gehorsam, Reynlickeit, woyllich Armoyt, en clara alusión a la reforma. En efecto, la pintura fue realizada entre 1460 y I470, coincidiendo por lo tanto con la reforma, que tras diez años de lucha concluyó el 6 de noviembre de 1466. 
sitúan en las prácticas de los peregrinos en los Santos Lugares, custodiados por los franciscanos desde 1342, otros consideran que el proceso fue a la inversa, esto es, el Vía Crucis habría tenido su origen en el área flamenca, siendo introducido posteriormente en Jerusalén (Da Zedelgem, 2004, p. I05). ${ }^{17}$ En todo caso, parece claro que tal devoción fue el resultado de intercambios entre Europa y Tierra Santa y que su origen no fue anterior a finales del siglo Xv. Desde Flandes, la práctica del Vía Crucis parece haberse difundido en España, donde los frailes menores habrían añadido ya a inicios del siglo xviı las dos últimas estaciones (Mazzone, 2006, p. I4).

Sin embargo, como se ha visto en las páginas precedentes, una vez más existen ejemplos en la Orden de Predicadores —el de Suso en el siglo xiv y el de Álvaro de Córdoba en el xv, además de las referidas prácticas de los monasterios femeninos-, que ponen de manifiesto el papel que también jugó la Orden de Predicadores en su creación y difusión, poniendo en duda la exclusividad y preeminencia de los Menores.

Para terminar, cabe recordar una vez más cómo el desarrollo de estas y otras prácticas varió notablemente de unos lugares a otros, influidas por la liturgia local, algo que se dio de forma más acusada en los monasterios femeninos. Es más, en muchos casos, más que en la obra de Suso, Álvaro de Córdoba u otros dominicos, debemos buscar el origen de ciertas devociones, procesiones y celebraciones en la costumbre local. Como se ha señalado líneas arriba, las monjas reprodujeron con frecuencia las procesiones que tenían lugar en el entorno urbano. Así, las dominicas de Santo Domingo de Lekeitio siguieron la práctica local de subir al monte Lumetxa donde existía una reproducción del Calvario (Velilla Iriondo, 1993, p. I30; Archivo del monasterio de Santo Domingo, Crónica de Santo Domingo de Lekeitio, II, XXI, p. 48).

De igual modo, el uso del Stabat Mater como secuencia litúrgica en un gradual-kyrial de Santa María Magdalena de Val di Piedra en Bologna, puede relacionarse a mi juicio con la liturgia local. En torno al tercer decenio del siglo XIV estas dominicas bolońesas incorporaron a un códice anterior la que hasta la fecha es la más temprana versión del Stabat Mater como secuencia y no como

${ }^{17}$ Según los partidarios de esta última hipótesis, los orígenes del Vía Crucis de catorce estaciones actual se sitúa claramente en el área flamenca entre los siglos XV y XVI, y nos es conocida a través de las obras de diversos autores, como Juan van Parchen, Pierre Sterckx, Bethelem, el anónimo de Saint-Trond, y sobre todo el holandés Adrichomius. Este último fue autor de dos obras fundamentales que contribuyeron a difundir un Vía Crucis de doce estaciones, en el que solo faltan la escena del Descendimiento y el Santo Sepulcro, para poder equipararse a la devoción actual. 
himno (Museo Civico Medievale de Bolonia, Ms. 5I8; Roncroffi, 2009, pp. 77 y 150). Esta se construyó en contrafactum sobre la melodía preexistente de la secuencia In caelesti Ierarchia, en honor de Santo Domingo, lo cual nos habla de la importancia de la festividad o celebración a la que estaba asociada. Sin embargo, determinar esta última ha resultado complicado, dado que la presencia del Aleluya — cuya inicial se decora con Santa Elena adorando la Cruz y los instrumentos de la Pasión en la zona superior y un grupo de dominicas orantes en la inferior- excluye su pertenencia al Tiempo de la Pasión o al Triduo Sacro. Se ha relacionado, en cambio, con las dos fiestas de la Cruz - la Invención, el 3 de mayo, y la Exaltación de la Cruz, el I4 de septiembre- aunque el verso aleluyático, que hace alusión a la flagelación, coronación de espinas y Crucifixión, no parece encajar con estas festividades. A fin de conciliar todos estos elementos, Ruini ha propuesto como segunda opción, su posible pertenencia a una fiesta votiva local o propia del monasterio (Ruini, 20IO, pp. 212-237). A mi juicio, la clave de este asunto puede estar en el contexto religioso local, y en concreto en la referida "Gerusalemme bolognese", esto es, en el conjunto de iglesias de Santo Stefano. La aparición del Stabat Mater en forma de secuencia nos está hablando probablemente de su canto procesional, algo que por otra parte, fue establecido oficialmente por Clemente XII en I73I, cuando reguló definitivamente la práctica del Vía Crucis. La secuencia sería entonada procesionalmente por las monjas mientras recorrían distintas capillas o estaciones, situadas en distintos lugares o dependencias del recinto monástico, en conmemoración de la Pasión. Por otra parte, la reutilización de la melodía de la secuencia de Santo Domingo, además de ser una práctica habitual en el medievo, no debió ser casual. Por el contrario, debió haber buscado de forma deliberada vincular la conmemoración de la Pasión a la memoria de Santo Domingo, quien, como se ha visto en el caso de las pinturas de Teitipac, y parece haberse predicado en ciertos sermones (Robles Sierra, p. 374), fue, al igual que San Francisco, otro Alter Christus. ${ }^{18}$

I8 Según informaba Baltasar Quiantana a finales del XVII, en Caleruega, había sido predicado un sermón inspirado en el Retablo de la Vida de Cristo de Juan de Padilla, una de las más famosas Vitae Christi de la primera mitad del xvi en España, en el que se vinculaba a Santo Domingo con las Cinco Llagas, que el santo calerogano habría tenido desde su nacimiento’ 
ALGUNAS CONSIDERACIONES SOBRE EL ESTUdIO DE LA LITURGIA PROCESIONAL 233

REFERENCIAS BIBLIOGRÁFICAS

Álvarez Pellitero, A.M., 1985: "Aportaciones al estudio del teatro medieval en España”, El Crotalón 2, pp. 13-35.

Ara Gil, C.J, Las Edades del Hombre, Remebranza, Zamora, 200I, pp. 623-62.

Arriaga, G., 1972 [1650]: Historia del Convento de San Pablo de Burgos, Fernán González. I (ed.), Burgos.

Berthier, J.P., I889: La Vergine acheropita dei Santi Domenico e Sisto a Roma, Ferrara.

Bonniwell, W. R., 1945: A history of the Dominican Liturgy (I215-1945), New York.

Boyton, S., 2007: "Prayer as Performance in Eleventh and Twelfth-Century Monastic Psalters", Speculum 82, pp. 895-93.

Buenaventura., I898: Legende duae de vita S. Francisci Seraphici, X, 7, Quaracchi.

Burgoa, F., 1989 [1674]: Geográfica descripción de la parte septentrional del polo ártico de la América y nueva iglesia de las indias occidentales, y el sitio astronómico de esta provincia de predicadores de Antequera valle de Oaxaca, México, 1989 (2 Vols.) [Edición original México, I674].

Constitutiones et acta Capitulorum Generalium Ordinis Fratrum Praedicatorum: I232-200I, 2002, Digitale Bibliothek Spezial, Berlín.

Candelaria, L., 2008: The Rosary Cantoral. Ritual and Social Design in a Chantbook from Early Renaissance Toledo, Rochester.

Carrero Santamaría, E., 20I0: "Crucificados, imaginería y liturgia pascual. La interacción entre el rito y su expresión material”, en Campos y Fernández de Sevilla, F.J (coord.), Los Crucificados, religiosidad, cofradias y arte: Actas del Simposium 3/6-9-20I0, El Escorial, pp. 75-92.

Casillas Garcia, J.A., 2003: El convento de San Pablo de Burgos: historia y arte, Salamanca.

Cátedra, P.M., 2005: Liturgia, poesía y teatro en la Edad Media. Estudios sobre prácticas culturales y literarias, Madrid, 2005.

Cerrato Mateos, F., 2005: El Cister de Córdoba. Historia de una clausura, Córdoba.

Creytens, R., 1965: "La riforma dei monasteri femminili dopo i Decreti Tridentini", en Il Concilio di Trento e la riforma tridentina, atti del Convegno storico internazionale, Trento, 2-6 settembre 1963, Roma, 1965, vol. I, pp. 45-85.

Dávila Padilla, A., 1955: Historia de la fundación y discurso de la Provincia de Santiago de México, de la Orden de Predicadores, México [primera edición Madrid i596]. 
Da Zedelgem, A.T., 2004: Saggio storico sulla devozione alla Via Crucis. Evocazione e rappresentazione degli episodi e dei luoghi della Passione di Cristo, Amilcare Barbero, A y Magro, P (eds.), [Traducción del texto original ı949: "Aperçu historique sur la dévotion au chemin de la croix”, Collectanea Franciscana]

Donovan. R.B.,I958: The Liturgical Drama in Medieval Spain, Toronto.

Escalante Gonzalbo, P., 2005: "Elogio de la cofradía y arraigo de la fe. La pintura mural de la capilla abierta de San Juan Teitipac, Valle de Oaxaca”, en Vargaslugo, E (ed.), Imágenes del indio en el arte colonial, México, pp. IO4-II4.

Estrada de Gerlero, E., I983: "El programa pasionario en el convento franciscano de Huejotzingo", Jahrbuch für Geschichte von Staat, Wirtschaft und Gesellschaft Lateinamerikas (Köln), vol. 20, pp. 642-662.

Feuillet, J.B., I678-I680: L'Année dominicaine, ou les Vies des saints, des bienheureux, des martyrs et des autres personnes illustres... de l'ordre des FF. Prêcheurs, pour tous les jours de l'année, avec un martyrologe, Amiens, 3 vol.

Franco Mata, A., 2007: "Tríptico de la Pasión de Cristo", Canciller Ayala (Catedral Nueva María Inmaculada, Vitoria, I8 de abril a 26 de julio de 2007), Vitoria, 2007, pp. 436-439.

Fueyo Suárez, B., 2009: "Secciones castellanas del breviario 06/508 de Santo Domingo el Real de Toledo", Ciencia Tomista, vol. 136, nº 2, pp. 363-396.

_, 20IO: "El processionarium OP de Salamanca (ms. San Esteban Sal.-CL.oI), Archivo Dominicano, XXXI, pp. 59-Ioo.

Galán Vera, M.J; Martínez Gil, C; Peñas Serrano, P., 2005: "La música en los conventos dominicos de Toledo (siglos XVI-XVIII)", Anales Toledanos 4I, pp. 255316.

Gilardi, C., 2006: "Liturgia, cerimoniale e architettura secondo l'ecclesiasticum Officium dei Fratri predicatori", en Cervini, F y Spantigati, Carla E (eds.), Il tempo di Pio V, Pio V nel tempo :atti del convegno internazionale di studi, Bosco Marengo, Alessandria, II-I3 marzo 2004, Alessandria, 2006, pp. I-77.

Hamburger, J. F, I992: "Art, Enclosure and the Cura Monialium: Prolegomena in the Guise of a Postcript", Gesta XXXI/2, pp. I08-I34.

—, 2000: "Offices des Morts et Processionnaux selon l'usage des dominicains", en Blondel, M; Hamburger, J.F; Leroy, C(Comisarios), Les dominicaines d'Unterlinden, Exposition, Musée de Unterlinden, Colmar, Io de décembre 2000Io juin 200I, París, 2000, vol. II, pp. 78-79.

Hernández Redondo, J.I., 200I: "En torno al maestro de Covarrubias", Actas del Congreso Internacional sobre Gil de Siloe y la Escultura de su época, Burgos I3-I6 de octubre de 1999, Centro Cultural "Casa del Cordón", Burgos, pp. 239-262 
Horcasitas, F., 2004: Teatro Náhuatl. Épocas Novohispana y Moderna, México [Primera edición México, 1974].

Jäggi, C., 2000: "Architecture et disposition liturgique des couvents féminis dans le Rhin supérieur aux XIII ${ }^{\mathrm{e}}$ et XIv ${ }^{\mathrm{e}}$ siècles", en Blondel, M; Hamburger, J.F; Leroy, C(Comisarios), Les dominicaines d'Unterlinden, Exposition, Musée de Unterlinden, Colmar, Io de décembre 2000 - Io juin 200I, París, 2000, vol. I, pp. 89-IO7.

Koudelka, V.J., 196r: "Le monasterium tempuli et la fondation dominicaine de San Sisto", Archivum Fratrum Praedicatorum, 3I, pp. 5-8I.

Martín González, J.J. y De La Plaza Santiago, F.J., 1987: Catálogo monumental de la Provincia de Valladolid, Tomo XV, Parte Segunda, Monumentos religiosos de la ciudad de Valladolid (Conventos y Seminarios), Valladolid, pp. 49-63.

Martínez Caviro, B., 1990: Conventos de Toledo, Castilla Interior, Toledo.

Martínez Vázquez, F., I975: Reseña histórica y catálogo documental Reseña histórica y Catálogo Monumental del Monasterio de Quejana, I374-1974, Sexto Centenario, Vitoria.

Mazzone, U., 2005: "Nascita, significado e sviluppo della Via Crucis", en Cerboni Baiardi, A(comisario), Viae Crucis, Espressioni artistiche e devozione popolare nel territorio di Pesaro e Urbino, Bologna, 2006, pp. II-20.

Medrano, M. J., I725-I734: Historia de la Provincia de España de la Orden de Predicadores, Madrid.

Moreau-Rendu, S., 1968: Le prieuré royal de St-Louis de Poissy, Colmar.

Morini, G; S. Niccoli, S y D. Palamedi, D., I997: "Un edificio da riscoprire: la Scala Santa in San Niccolò", Prato Storia e Arte 90-9I, XXXVIII, p. II7.

Melero Moneo, M.L., 2000-200I: "Retablo y frontal del convento de San Juan de Quejana”, Locus Amoenus, 5, pp. 33-51.

Navarro Talegón, J., 1980: Catálogo monumental de Toro y su Alfoz Ordinarium iuxta ritum sacri Ordinis Fratrum Praedicatorum, 1921 [1256], ed. Guerrini, F.M., Roma.

Pais, A y Curvelo, A., 2009: "Memórias da Fogueira. O primitivo mosteiro da Madre de Deus", en Curvelo, A. (ed.), Casa Perfeitíssima: 500 anos da Fundação do Mosteiro da Madre de Deus, 1509-2009, Lisboa, pp. 75-83.

Pérez Vidal, M., 20I2: "Observancia y rigorismo. Consecuencias de la reforma de la Orden de Predicadores y de algunos movimientos rigoristas en la liturgia y arquitectura de los monasterios de dominicas de la Provincia de España”, en Fernández Rodríguez, N. y Fernández Ferreiro, M. (eds.), Literatura medieval y renacentista en España: líneas y pautas. Actas del III Congreso Internacional de la SEMYR, Celebrado en Oviedo del 27 al 30 de septiembre de 20I0, Salamanca, pp. 799-8IO. 
—, 2013: Arte y arquitectura de los monasterios de la Orden de Predicadores de la "Provincia de España". Desde los origenes hasta la reforma (I2I8-I506), Tesis doctoral inédita, Universidad de Oviedo, 2013.

Prieur, J., 1983: Das Kölner Dominikanerinnenkloster St. Gertrud am Neumark, Köln.

Robles Sierra, A., 1995: "El P. Baltasar de Quintana y su información sobre Caleruega”, en Aniz Iriarte, C. y Díaz Martín, L .V, Santo Domingo de Caleruega. Contexto Cultural III Jornadas de Estudios Medievales, Salamanca, pp. 36I-380 Roncroffi, S., 2009: Psallite Sapienter. Codici Musicali delle Domenicane Bolognesi, Firenze.

Rosell y Torres, I., I875: "La Madona de Madrid, antigua imagen del demolido monasterio de Santo Domingo el Real", Museo Español de Antigüedades, V, pp. I63-I73.

Rouanet, L., I90I: Coleción de autos, farsas y coloquios del siglo XVI, Barcelona, 4 vols.

Rucquoi, A., 1998: "Ildefonse de Tolède et son traité sur la Virginité de Marie", en La Virginité de Marie, Etudes Mariales. Bulletin de las Société française d' études mariales, París, 1998, pp. I05-I25.

Rudy, Kathryn., 20II: Virtual Pilgrimages in the Convent, Imagining Jerusalem in the Late Middle Ages, Turnhout.

Ruini, C., 20Io: “Un' antica versione dello Stabat Mater in un Graduale delle domenicane bolognesi”, Philomusicaon-line,9/3, 2010, pp. 212-234<http:// riviste.paviauniversitypress.it/index.php/phi/article/view/6I6> [últimaconsulta I de octubre de 20I4].

Schmidt, V. M., 2009: "Ensembles of Painted Altarpieces and Frontals", en Kroesen. J y Schmidt, V. M. (eds.), The Altar and its Environment (II5O-I400), Turnhout, 2009, pp. 203-222.

Surtz, R.E., 1979: The Birth of a Theater. Dramatic convention in the Spanish theater from Juan del Encima to Lope de Vega, Princeton, 1979.

—, 1983: "The Franciscan Connection in the Early Castilian Theater", Bulletin of the Comendiantes, 35, pp. I4I-I52.

Tormo y Monzó, E., 1916: "El retablo de Quejana del Canciller de Ayala. Una nota bibliográfica y algo más", Boletín de la Sociedad Española de Excursiones, XXIV, pp. I52-I60.

Velilla Iriondo, J, I993: “Origen y evolución de la Villa de Lekeitio", in: Cuadernos de Sección. Historia-Geografía 2I, pp. II5-I34.

Vetancurt, A. de., 1971: Teatro Mexicano, Descripción breve de los sucesos ejemplares, históricos y religiosos del Nuevo Mundo de las Indias. Crónica de la Provincia 
del Santo Evangelio de México, México [Ed. facsímil de la primera edición México, I698].

Vidal, C.J., 1946: Breve reseña histórica del convento de Santo Domingo el Real de Madrid, desde su fundación por el mismo Santo Patriarca, año del Señor de I2I8, Impr. y Librería del Seminario Conciliar. Santiago de Compostela.

Webster, S.V., 1997: "Art, Ritual and Confraternities in Sixteenth Century New Spain”, en Anales del Instituto de Investigaciones Estéticas, pp. 5-39.

Wilkins, C.L., I998: Constanza de Castilla, Book of Devotions-Libro de devociones y oficios, Exeter.

Yardley, A.B., 2009: "Clares in Procession: The Processional and Hours of the Franciscan Minoresses at Aldgate", Women and Music: A Journal of Gender and Culture I3.I, pp. I-23. 


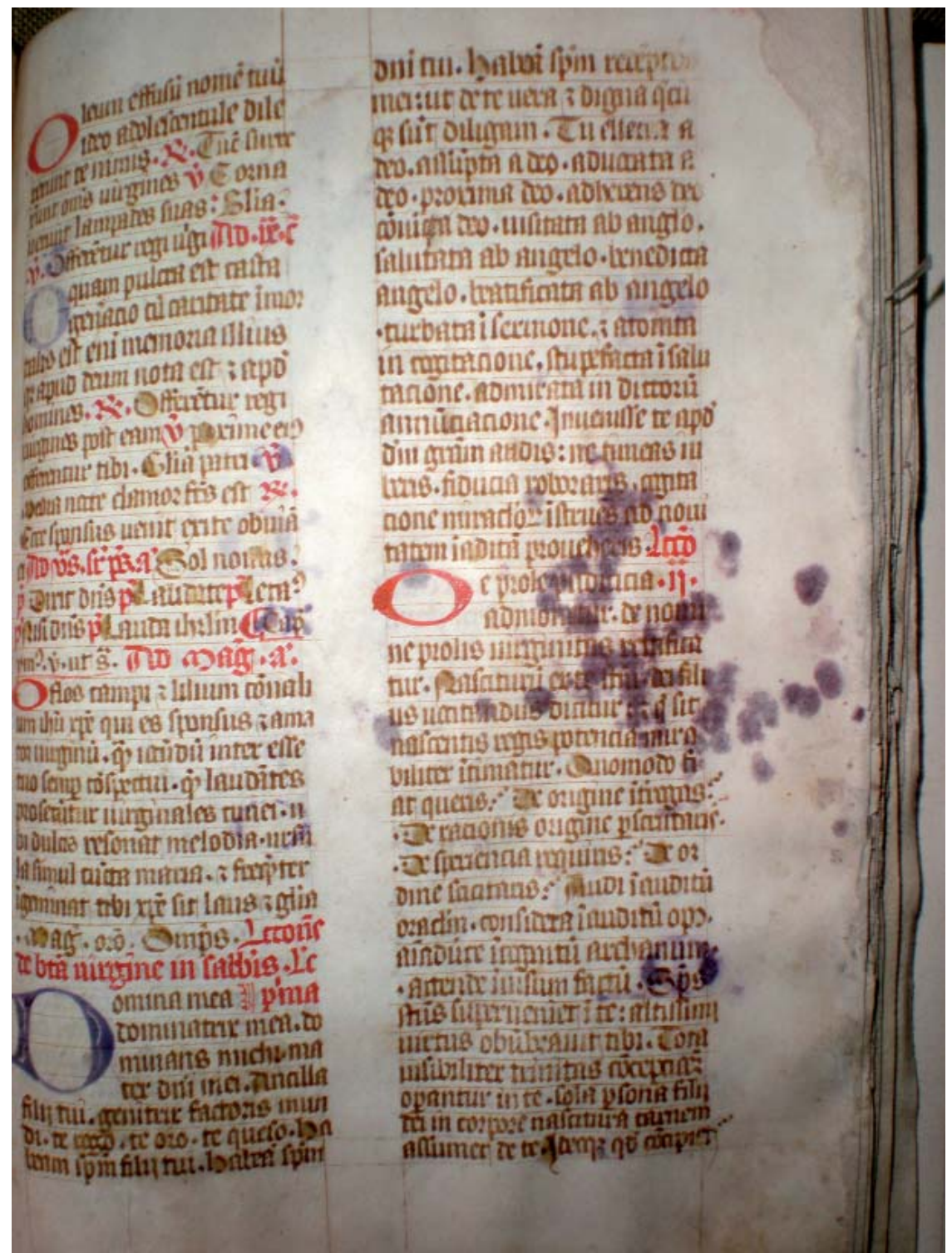

Fig. I. Lectiones de Beata Virgine in Sabbatis.

Breviario portátil de Santo Domingo de Toledo, ff. 343r-344v (ca. I460-I470). Archivo Santo Domingo el Real de Toledo, Ms 06/508 


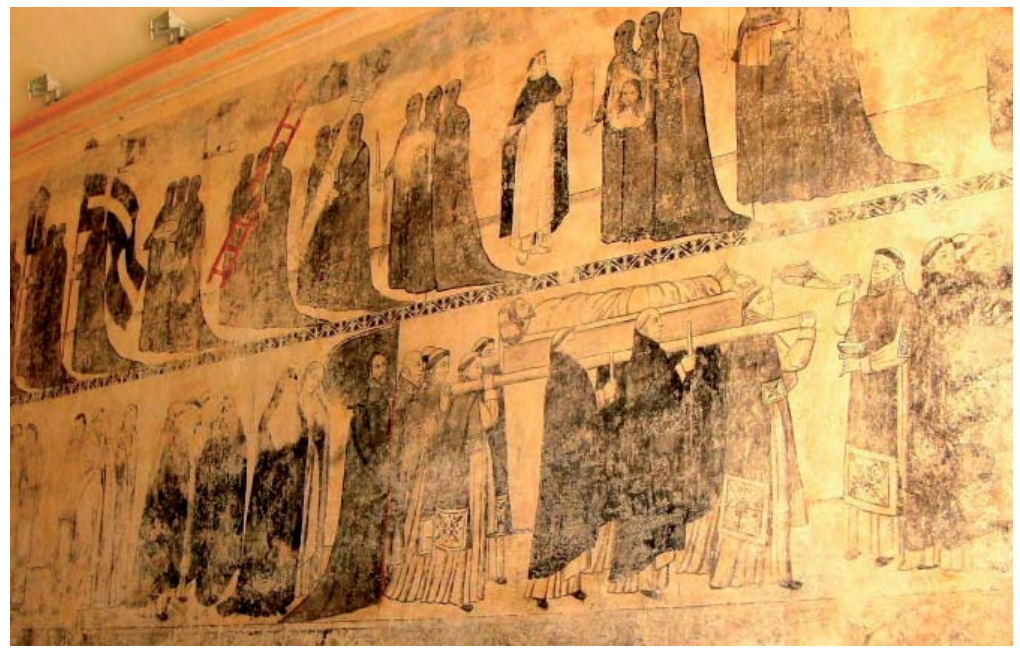

Fig. 2. Procesión del Santo Entierro. San Juan Bautista de Teitipac (Oaxaca). Foto: M. Pérez Vidal.

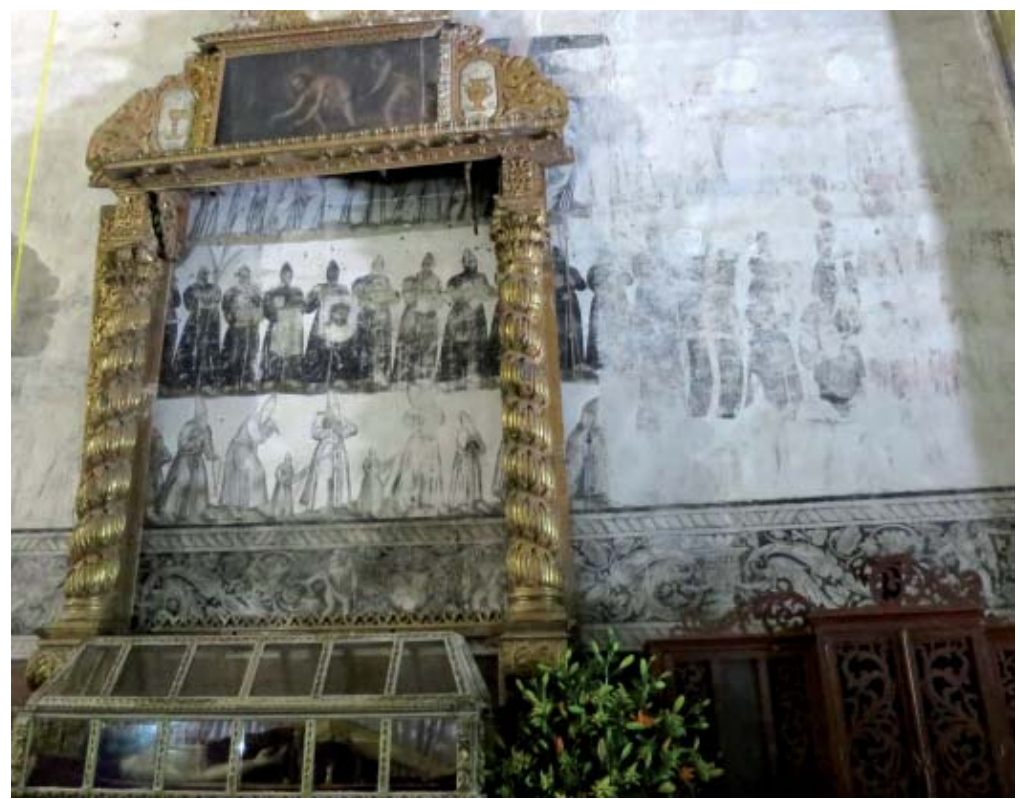

Fig. 3. Procesión del Santo Entierro Huejotzingo (Puebla). Foto: M. Pérez Vidal. 


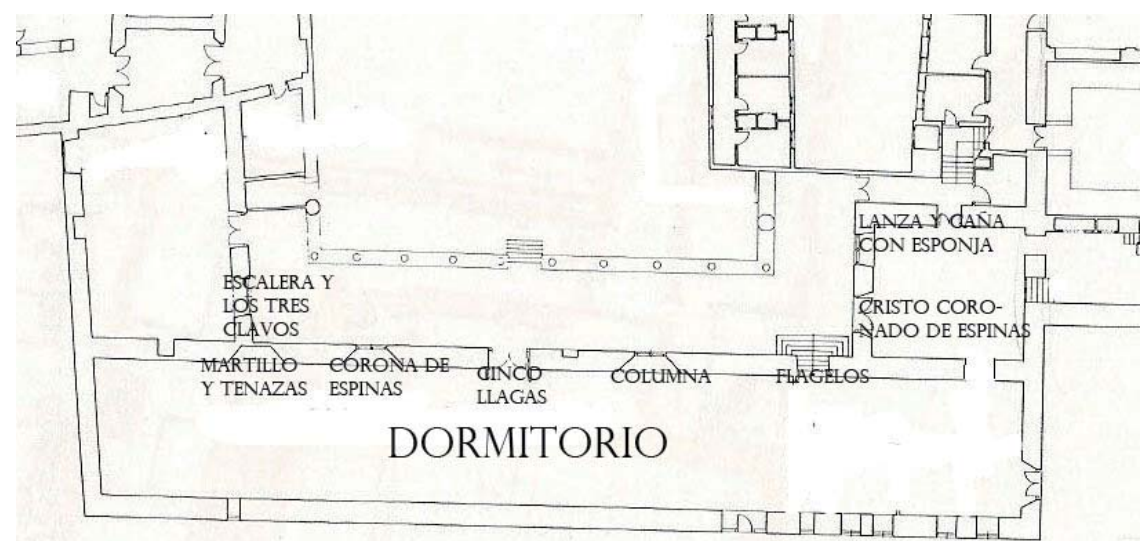

Fig. 4. Estaciones con los Arma Christi en el claustro del Moral de Santo Domingo el Real de Toledo.

M. Pérez Vidal sobre plano del instituto Geográfico y Estadístico, I88I. 


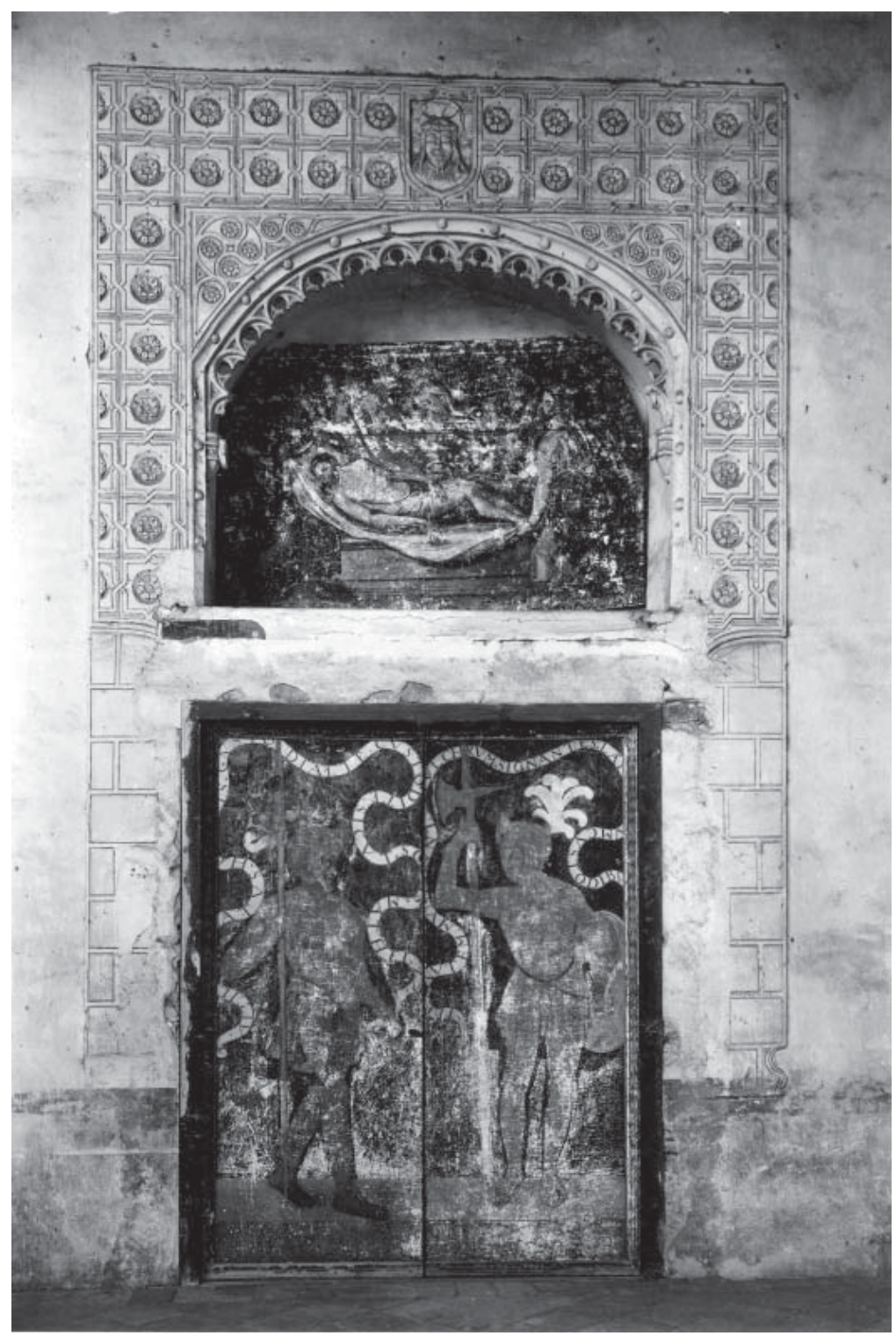

Fig. 5. Representación del Santo Entierro en el Claustro del Moral, Santo Domingo el Real de Toledo. Archivo Histórico Provincial de Toledo, Fondo Rodríguez F-039. 


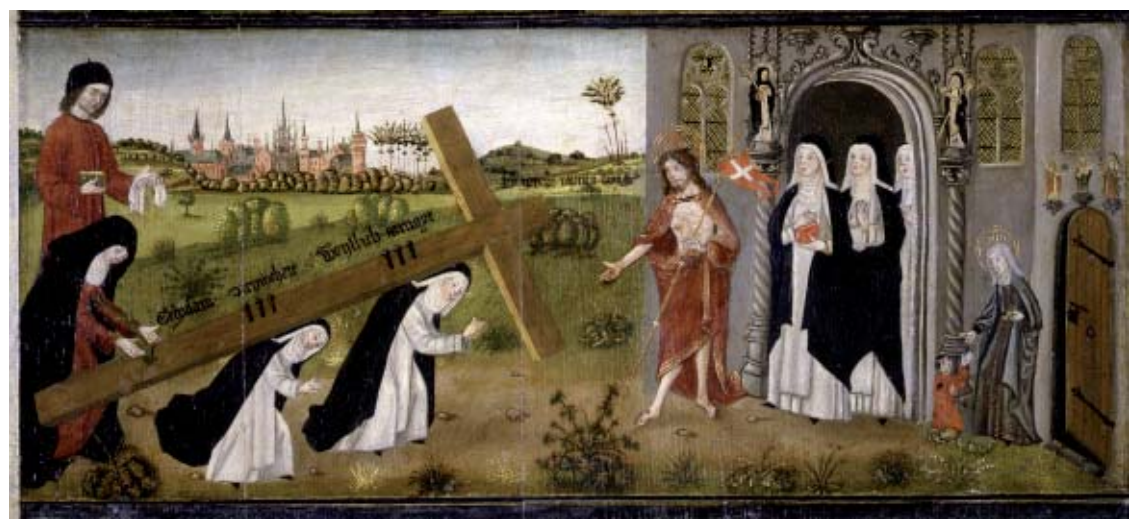

Fig. 6. Panel central de retablo procedente de St. Gertrud Köln (I460-I470). Wallraf-RichartzMuseum-Fondation Corboud, Nr. WRM 0342. (@) Rheinisches Bildarchiv, RBA_c020465) 